\title{
Om inteendeel te sê: oor selfskepping - wanneer lewe en vertel deurmekaar raak
}

\author{
Willem Burger \\ Departement Afrikaans \\ Universiteit van Zoeloeland \\ EMPANGENI
}

\begin{abstract}
To say "on the contrary": On self-creation - when life and narration merge

In Brink's novel, Inteendeel (On the Contrary) of 1993, Estienne Barbier rewrites his life while imprisoned in the Dark Hole. A close relationship between life and narration thus develops. This problematic relation is often foregrounded in metafictional texts. On the one hand, mimetic representation of reality is undermined, while on the other, the textuality, the linguistic quality of life, is emphasized. The dialogic character of self-creation prevents this metafictional text, in which self-creation also plays an important role, from being narcissistic. It is also argued that self-creation and metafictional comments are processes by means of which the aesthetic dimension and life merge, with the hope of creating a more humane world.
\end{abstract}

\section{Inleiding}

In Brink se Inteendeel (1993) is Estienne Barbier besig om sy eie lewe te herskryf vanuit die Donker Gat. 'n Noue verband ontstaan tussen 'lewe' en 'sê'. 'n Storie word vertel: "Om die grense te toets van wat gesê kan word. Om die grense te bevestig van wat reeds gesê is. Om die grense van die self te lewe" (288)'.

Hierdie problematiese verband tussen lewe en vertelling word voortdurend in metafiksionele tekste op die voorgrond geplaas deur die aandag op die talige aspek van die vertelling te vestig ${ }^{2}$. Die moontlikheid om die werklikheid mimeties

Alle bladsynommers tussen hakies verwys na Brink, A.P. 1993. Inteendeel. Kaapstad : Human \& Rossouw.

2 Bertens en D'Haen (1988) tel onder die talle besprekings van die sogenaamde postmodermisme - hicrdie besprekings dui aan hoe belangrik die rol van die twintigste-eeuse 
weer te gee word enersyds in sulke tekste ondergrawe. Andersyds word ook die tekstualiteit, die taligheid van die lewe beklemtoon.

In hierdie artikel word gefokus op die neiging by postmodernistiese tekste om selfgerig te wees. Daar word aangedui dat dié selfgerigtheid nie noodwendig as narsissisties beskou hoef te word nie ${ }^{3}$. Teoretici wys dikwels daarop dat metafiksionele tekste die blootlê van metaverhale ten doel het ${ }^{4}$. In Inteendeel word egter nie alleen gebly by die blootlê van metaverhale nie ('inteendeel sê' nie), maar die vertelling word ook kreatief aangewend om 'n lewe ('n self) te skep. Hierdie selfskepping van Barbier is 'n proses waardeur die estetiese en die lewe geïntegreerd raak, met die hoop om 'n meer menslike wêreld tot gevolg te hê.

\section{Lewe en vertelling (geskrif)}

Barbier se hele lewe is ' $n$ geskrif wat as brief aangebied word. Die roman begin met "Lectori salutem" en 'n adres (13) en eindig met die handtekening van Barbier (301). Dit is egter 'n "onmoontlike brief' (13), een wat Barbier nie self geskryf het nie. Die eerstepersoonverteller word reeds in die openingsin gerelativeer: "Ek is dood: jy kan nie lees nie: dié sal (daarom) nie 'n brief gewees het nie" (13). Later lê hy ook klem daarop dat hierdie brief waarin hy besig is om homself in te skryf nie werklik bestaan nie, aangesien hy nie eens pen of papier het nie (282). Die herbeskrywing self word gerelativeer.

Skrywe en lewe word eksplisiet verbind. Sy lewe is as't ware een lang brief: "My hele lewe lê in briewe uitgemors" (13). Dit wat Barbier hier aan Rosette skryf, is sy lewe.

Aan die einde vind Barbier vertroosting daarin dat hy besig is om sy eie lewe te skryf, dat die storie wat hy oor homself vertel, sy eie lewe bepaal: "Dit is nogal gerusstellend om te voel dat my eie storie my nou bepaal, soos wat ek dit vroeër versin het. Elke lewe is 'n geskrif. Net jammer die meeste van ons skryf so sleg" (282).

linguistiek op postmodernistiese literatuur was. Bertens en D'Haen bespreck die wyse waarop die talige aspek deur middel van metafiksie, intertekstualiteit, intrige, verteller, personasie ensovoorts op die voorgrond geplaas word.

3 Vergelyk byvoorbeeld Hutcheon (1984).

4 Let byvoorbeeld op McHale (1987:148) wat telkens aandui hoedat 'rame' doclbewus in postmodemistiese tekste gebreek word, sodat die leser van hierdie grense/ rame bewus kan word. 
Probleme word gewoon toegeskryf aan swak skrywerskap. Elkeen word gemeet aan die mate waarin $\mathrm{h} / \mathrm{sy}$ daarin slaag om hom/haarself te herskep deur die self te herskryf.

Tydens sy laaste reis is Barbier tevrede met sy selfskepping. Hy het homself losgeskryf van die verlede. Hy het niks meer nodig nie: "Ek is selfgenoegsaam", (282) verklaar hy onomwonde. Hy het homself suksesvol geskryf: "Miskien is ek vry. Estienne Barbier: wat ek ook al bestem is om te wees, is ek vinnig aan die word" (282).

Hy begin sy outentieke self ervaar. Deur sy eie lewe te vertel as storie, vorder Barbier nader aan die ideaal van outentisiteit.

'n Persoon wat na sy eie outentieke self soek, noem Rorty (1989) 'n ironis. 'n Ironis is vir hom iemand wat homself nie laat definieer deur sy voorgangers ${ }^{5}$ nie. Die ironis is voortdurend besig om homself, in sy eie terme, te omskryf. Daar word aan die self uitdrukking gegee deur die self te vertel. Rorty (1989) praat van die skep van 'n eie woordeskat. Om 'n eie woordeskat te skep beteken dat die verlede herbeskryf moet word om sodoende die houvas daarvan te verbreek. Dit word veral gedoen deur die verlede te ironiseer.

In hierdie herskrywing val die klem op die self-kreërende aard van die lewe. Elke mens kan (en moet) sy eie lewe skryf. Sukses word nie gemeet aan kriteria van buite (een of ander hoofletterwoord soos Being, Truth, History, Absolute knowledge, Will to Power (Rorty, 1989:107)) nie, maar aan die self, die mate waarin geslaag is om die self te skep, om die norme te skep waaraan die self beoordeel moet word6). Hierdie sukses is binne die bereik van die selfskeppende individu. (Mislukking kan immers toegeskryf word aan swak skrywerskap.)

Die 'ideaal van outentisiteit' - 'n morele ideaal om getrou aan jouself te wees (Taylor, 1991:15) behels dus dat oorgeërfde beskouings vervang word deur selfgemaakte beskouings. Belangrik in hierdie verband is dat hierdie 'selfgemaakte' woordeskat steeds geïroniseer moet word.

$5 \quad$ In die geval van filosowc - die Plato-Kant-tradisic.

6 "The gencric task of the ironist is the one Coleridge recommended to the great and original poet: to create the taste by which he will be judged. But the judge the ironist has in mind is himself He wants to sum up his life in his own terms. The perfect life will be one which closes in the assurence that the last of his final vocabularies, at least, really was wholly his." (Rorty, 1989:97.) 


\section{Positiewe aanwending van twyfel in meesterverhale: selfskepping}

Lyotard se The Postmodern Condition (1984) is 'n ondersoek na die stand van kennis in 'n hoogs tegnologiese samelewing. Sentraal in sy redenasie staan dat wetenskaplike, analitiese kennis nie in staat is om sigself te legitimeer nie. Dit is altyd nodig om sekere meesterverhale oor kennis te aanvaar.

In ons hoogs tegnologiese samelewing staan wetenskap en narratief in konflik teenoor mekaar. Volgens die maatstawwe van die wetenskap is narratiewe slegs fabels, terwyl wetenskap met 'feite' besig is. Wetenskap is egter nie alleen besig met die formulering van nuttige algemeenhede en die soeke na waarheid nie. Lyotard wys daarop dat die wetenskap ook verplig is om die reëls van sy eie spel te legitimeer (elke spesifieke wetenskap bepaal wat vir dáárdie wetenskap as wetenskaplik korrek aanvaar word, wat waar is, wat nie waar is nie, wanneer 'n bewys geldig is ens.). Hierdie legitimisering word 'n afsonderlike diskoers - die diskoers ten opsigte van die legitimering van eie status - en word deur Lyotard die 'metaverhaal' van die spesifieke wetenskap genoem.

Net soos 'n besondere metaverhaal 'n spesifieke wetenskap legitimeer, vind elke metaverhaal weer op sy beurt legitimering in die meesterverhaal. Die besef dat sogenaamde 'wetenskaplike kennis' op narratiewe berus vir legitimering, lei tot wantroue teenoor enige 'feite' en waarheidsaansprake. Postmoderniste staan wantrouig teenoor enige metanarratief: "Simplifying to the extreme, I define postmodern as incredulity toward metanarratives" (Lyotard, 1984: xxiv).

Hierdie verlies van geloofwaardigheid van alle metanarratiewe kan moontlik lei tot 'n negatiewe reaksie van onsekerheid. In postmodernistiese tekste word hierdie verlies egter meestal op vrolike wyse gevier?. Hierdie tweede, positiewe reaksie, is ook teenwoordig in die werk van Rorty (1989). Die positiewe aspek van die besef dat alle wetenskaplike kennis op narratiewe berus, is dat dit inhou dat die legitimerende narratiewe deur die individu herskryf kan word. Rorty beklemtoon die skeppende vermoë van die individu. Taylor (1991) wys daarop dat hierdie klem op selfskepping wortels in die Romantiek het. Ook Waugh (1992) redeneer dat die Postmodernisme eintlik nie 'n begin van iets is nie maar 'n belangrike uitvloeisel van die Romantiek: "Postmodernism as an aesthetic body of thought can be seen as a late-flowering Romanticism" (Waugh, 1992:3). Sy plaas groot klem op die rol van die estetiese in die Postmodernisme. Vir haar is daar in die Postmodemisme en in die Romantiek 'n kritiek op die Verligting se geloof in die

7 Vir 'n bespreking van die viering van die wantroue ten opsigte van metaverhale, kyk na Burger (1994). 
rasionele. In sowel die Postmodernisme as die Romantiek is daar 'n erkenning van die estetiese as mag waardeur nuwe werklikhede geskep kan word (Waugh, 1992:18).

In Inteendeel word die ideaal van selfskepping deur Barbier nagestreef deur 'inteendeel' te sê (deur die vertellings van ander, die metaverhale, te verwerp), en dan die self te skep (deur die vertel van die self - 'n storie waarin die self geskep word).

\subsection{Om inteendeel te sê}

Om die self te skep moet die voorgangers se houvas eers verbreek word. Verset teen die beskrywings van die voorgangers is noodsaaklik om metaverhale bloot te lê; in die eerste plek moet die voorgangers se houvas gebreek word - dit is nodig om 'inteendeel' te sê. Barbier is nie bereid om sy lewe te laat beskryf deur sy ouers, eggenotes, geliefdes, of enigiemand anders nie (hy laat immers gebroke verhoudings en teleurstellings agter so ver hy gaan). Sy reaksie op alle pogings om hom te beskryf is om 'inteendeel' te sê.

Hierdie weiering bring hom voortdurend in botsing met ander. Hy weier byvoorbeeld reeds om die joernaal te plooi volgens Alleman se wil. Dit wat hy hoop om te beleef word vir hom belewenis: "Waarna ek hunker, is die ontdekking van iets heeltemal nuuts, nog sonder naam, skaars benoembaar, iets wat geen menseoë nog aanskou het nie, aarde wat nog g'n mensespoor vertoon nie. In die heel laaste instansie, Monomotapa" (22).

In Rorty se terme: Barbier wil 'n eie woordeskat skep wat van sy voorgangers s'n verskil. Hy wil self die reëls maak waarvolgens hy lewe.

Jean het die eerste keer aan Barbier verskyn omdat hy 'nee' geroep het; die verset om sy lot te aanvaar uitgespreek het (294). Wanneer Barbier besluit om te ontsnap, herinner Jeanne hom daaraan dat ontsnappingsmoontlikheid die laaste waardigheid van 'n gevangene is. Die wil om te ontsnap, die wil om vry te wees kan nie weggeneem word van 'n gevangene nie - alle ander dinge wel. Solank daardie wil bestaan, is 'n mens nog vry. Sy sê dat die enigste manier om mens te bly, is deur 'nee' te sê (172). Deur nee te sê, deur inteendeel te antwoord, kan 'n mens steeds jouself wees. Dit is die enigste manier om nie toe te gee aan die druk van die gemeenskap om jou individualiteit te laat vaar nie. Die ideaal van outentisiteit kan slegs verwesenlik word deur 'nee' te sê, deur 'inteendeel' te sê. Hy bly weerstand bied teen elke vorm van gesag, elke vorm van gesag rus op 'n metanarratief en is nie selflegitimerend nie. Hy verwerp die gesag van Alleman en die hof. Hy sê selfs inteendeel wanneer sy tante Celliers hom die plaas aanbied. Hy weier om hom te laat inskryf in 'n rustige bestaan as boer. 


\section{2 'n Eie woordeskat}

Om inteendeel te sê is die verwerping van ander se beskrywings, ander se woordeskatte; om inteendeel te sê impliseer om die legitimiteit van metaverhale te bevraagteken. Dit word vervang deur 'n nuwe woordeskat te skep: in die geval van Barbier deur die vertel van stories; deur die self te hervertel ${ }^{8}$.

\subsubsection{Storievertel as skepping}

Rosette vertel aan Barbier 'n skeppingsverhaal van 'n vrou wat die hele wêreld laat ontstaan het deur vertelling. Ook mense word sodoende deur haar vertelling geskep. En hierdie mense skep dan verder deur hulle eie stories te vertel (153154). Sodoende word bevestig dat die mens homself kan skep deur sy vertellings, soos wat Barbier ook inderdaad besig is om in hierdie teks te doen.

Die idee van selfskepping deur middel van stories word bevestig deur Jeanne se vertelling van hoe sy by die priester gaan bieg het. Sy sê dat sy besef het dat haar hele lewe, haar hele 'ek' vir die priester slegs bestaan uit dit wat sy aan hom vertel het:

Ek kon myself letterlik skep deur wat ek aan hom vertel. Ek kon myself heeltemal uitkanselleer deur stil te bly. Of ek kon ontelbare ekke skep deur verskillende stories te vertel. Van daardie oomblik af het ek volle beheer oor my lot oorgeneem. (158)

Jeanne het besef hoedat sy volle beheer oor haar lot kan oorneem deur stories te vertel. Dit is dan ook haar voorbeeld wat Barbier volg wanneer hy sy lewe in 'n boek met drie dele herskryf $(274)^{9}$.

\subsubsection{Stories maak die onmoontlike moontlik}

Die manier waarop 'n mens daarvan ontneem word om jou eie lewe te skryf, om jouself te bepaal, is wanneer die vermoë om stories te vertel belemmer word. Jeanne verduidelik aan Barbier dat mag bekom word deur die verbeelding aan bande te lê. Politici bekom mag, volgens hierdie redenasie, deur slegs op die moontlike te konsentreer:

8 Rorty (1989:118) wys in sy bespreking van Nietzsche, Heidegger en Proust daarop dat romanskrywers dikwels veel beter 'ironiste' is as teoretici (filosowe), aangesien laasgenocmde nie daarin slaag om ook hulself te relativecr nie.

9 Die reise as vertellings word bespreek in afdeling 3.2 .3 
Dis hulle almal se sonde, al die manne wat politiek bedryf asof dit 'n spel is, die spel van die moontlike. Hulle word magtig omdat hulle die verbeelding aan bande lê. Dis waarop hulle hele mag berus. Hulle verbied ons om te onthou wat regtig onmoontlik is. En deur net op die moontlike te konsentreer, sê ek jou, het hulle die wêreld 'n onmoontlike plek gemaak om in te woon. (151)

Metanarratiewe legitimeer dit wat moontlik is. Slegs deur die 'onwettige', die verbeelding, toe te laat, kan die mag van die metanarratief verbreek word. Om voortdurend na outentisiteit te streef, om stories te vertel, om die self te vertel, is om te veg teen die onmoontlik maak deur ander, teen die beperkings wat metaverhale op kennis plaas. Die ideaal van outentisiteit is om nie deur die moontlikhede wat ander daarstel, bepaal te word nie maar eie moontlikhede te skep dikwels juis ander se onmoontlikhede ${ }^{10}$. Wanneer beweeg word buite dit wat as legitiem aanvaar word, is so 'n diskoers 'waansinnig'. Foucault (1980) wys daarop dat dit nie moontlik is om buite die aanvaarde diskoers enige sinvolle diskoers te voer nie. In elke gemeenskap is daar reëls wat bepaal wat waar of onwaar is:

Each society has its régime of truth, its 'general politics' of truth: that is the type of discourse it accepts and makes function as true; the mechanisms and instances which enable one to distinguish true and false statements, the means by which each is sanctioned; the techniques and procedures accorded value in the acquisition of truth; the status of those who are charged with saying what counts as true. (Foucault, 1980:131.)

Hy vind dit byvoorbeeld moeilik om 'kranksinnige' diskoers te vind en lei hieruit af dat sekere reëls en prosedures bepaal wat as normaal of rasioneel geag word en sodoende verswyg wat buite hierdie reëls val. Dit is vir die individu nie moontlik om buite die heersende diskoers se reëls en prosedures te dink en skryf, sonder om as kranksinnig stilgemaak te word nie. Hierdie 'reëls', waardeur die diskoers bepaal word, word verder deur die vorming van die opvoedkundige stelsel ingeburger omdat dit opvattings oor wat rasioneel of 'wetenskaplik' is vaslê.

In hierdie verband is dit belangrik om te let op die rol van Don Quixote in Inteendeel. Quixote is 'n persoon wat buite die aanvaarde norme van sy tyd optree en daarom as kranksinnig beskou word. Dit is egter juis deur die verbeelding (stories) wat dit moontlik gemaak word om buite hierdie 'onmoontlike', dit wat

10 Die belang hiervan is dat elkeen vir homself sy eie moontlikhede moet skep, maar dikwels kan cen mens ook 'n ander se oe oopmaak om nuwe moontlikhede raak te sien: "Ons het iemand nodig om weer ons oe vir die onmoontlike oop te maak, Estienne. Dis al manier om die wêreld te verander in 'n plek waar lewe weer moontlik is" (152). Quixote se rol in hierdie verband is belangrik. 
buite die aanvaarde diskoersreels (metaverhaal) val, te beweeg en sodoende die metaverhaal, die diskoersreëls bloot te lê.

\subsubsection{Lewe en (vertelde) reis}

Die drie reise wat in Inteendeel verhaal word, is nóú verweef met die vertelling. Die laaste reis word inderdaad gelykgestel met 'n storie. Nadat hy telkens geslaan is, staan Barbier weer op "om jou strawwe storie verder op die voet te volg" (289). Die laaste reis word ' $n$ reis in die self in - 'n vertelling al nader aan die outentieke self. Daarom kan Barbier uiteindelik, teen die einde van hierdie reis, afskeid neem van sy reisgenoot, Khoib, van Jeanne, Quixote en Rosette.

Die reise deur die vreemde land word metafoor van die selfskeppingsproses. Dit word deur Barbier sélf gevestig deur sy opmerking dat die lig in hierdie land mense terugdwing in hulleself (78). Tydens die eerste twee reise is dit vir Barbier nie moontlik om die land werklik sélf te ervaar nie. Hy word gedwing om die land volgens Alleman se reisplan en wil te ervaar. Die eerste reis word boonop gedomineer deur sy eie meerderwaardigheidsgevoel as Europeër in 'n vreemde land. Hy vind die buitedistrikte wild en voel dat 'n "ferm hand" (25) nodig is om seker te maak dat die Europese beskawing nie verlore moet gaan nie. Hy beskryf die ekspedisie as "'n bedreigde maar onuitroeibare stroompie beskawing en edele aspirasies wat dag vir dag voortbeweeg deur 'n donker binneland, om dit te roer met geskiedenis en gewete" (25). Die inskripsie bokant die hospitaaldeur maak in hierdie stadium vir Barbier sin. Hierdie "marge van die beskaafde wêreld" (72) moet moet ook onder die orde en betekenis van die beskawing kom"1.

Barbier se 'kennis' van die land word tydens die eerste reis bepaal deur ' $n$ legitimerende metanarratief van Europese oorsprong - sekere beskouings van wetenskaplikheid, maniere van waameem en kategorisering. Reeds toe is daar opstand by Barbier teen die metanarratief. Die beskrywings wat hy gee van sekere diersoorte (eenhoring, hippogrief), voldoen nie aan die vereistes van wetenskaplikheid nie en word dus ook deur Alleman verwerp as waansinnige diskoers en moet oorgeskryf word volgens die eise vir legitimiteit. Die metaverhaal (dit wat as wetenskaplik, korrek, merkwaardig geag word) word deur die Kaapse owerheid bepaal (42).

Op die tweede reis word sy kennismaking met die land verhoed deur sy vrees (wat hy kollektief met die boere deel). Hierdie vrees word die dryfveer agter

11 Petzold vertaal vir Barbier die inskripsie bokant die deur van die hospitaal: "En die Afrikaaarde sidder voor jou wette" (150). (Belga tuum nomen populis falale domandis / Horreat et leges Africa terra tuas - 283.) 
hulle vernietiging en verwoesting - 'n selfvestiging gebore uit vrees lei slegs tot verwoesting:

Uiteindelik het ek iets begin verstaan van die drifte waarmee ek die afgelope maande saamgelewe het: die geweld, die energie, die oënskynlik uitbundige wreedheid, die drang om met brute geweld alle teenstanders, werklik of verbeel te onderwerp, die hartstog om te vernietig. Dit alles was nie die gevolg van oormoed of selfs van haat nie, maar van angs: 'n angs vir dié uitgestrekte land, vir sy ruimtes, vir sy ongenadige lig, vir wat skuilhou in dié lig, vir sy donker mense. (216)

Pas nadat hy die fortjie klaar gebou het, besef hy die nietigheid daarvan teenoor die groot kontinent en word hy gevul met vrees. Dit is eers wanneer hy hierdie vrees besweer, en die fort verlaat en sonder wapens en sonder klere op die derde reis, alleen, die binneland intrek, wat hy die land werklik leer ken: "Ek besit niks. Ek moet hulle van voor af leer ken: nie die name nie, maar die dinge self. Die klipheid van 'n klip, die koppigheid van 'n koppie, die doringheid van 'n doringboom, die stilte van stilte." (283)

Sodra Barbier besef dat die land ook 'n storie is, laat Khoib hom alleen om self die storielyn verder te volg (288). Barbier word gedwing om die reis op sy eie aan te durf. Die narratief word erken bo die eise van wetenskaplikheid.

\section{Selfskepping - narsissisties?}

Twee aspekte verdien hier aandag. In die eerste plek word die aandag gevestig op die dialogiese aard van hierdie selfskepping. Tweedens word gewys op die effek van die vermenging van die estetiese en die lewe.

\subsection{Die dialogiese aard van selfskepping}

Selfskepping van hierdie aard kan lei tot die siening dat die ideaal van outentisiteit 'n bloot private aangeleentheid is; ' $n$ narsissistiese selfbeheptheid. Vir Taylor (1991:33) moet die klem egter nie slegs op die selfskeppende moontlikhede val nie, maar ook op die dialogiese aard van selfskepping.

In die eerste plek rig Barbier sy vertelling van homself as 'n brief aan Rosette. Die brief is egter nie uitsluitlik aan haar gerig nie, maar begin met die aanhef "Lectori salutem" (13).

In die tweede plek vind hierdie selfskepping plaas teen 'n horison van 'betekenisvolle ander' (Taylor, 1991:33). Betekenisvolle ander impliseer vir Taylor (1991: 31-41) dat daar ' $n$ horison van betekenisvolheid bestaan. Om na die ideaal van outentisiteit te streef, om die wil te hê om sigself in eie woorde te beskryf, kan 
slegs betekenisvol wees indien dit teen 'n horison van betekenisvolheid gesien word. Wanneer enige individu meen dat hierdie ideaal van outentisiteit die moeite werd is, word daardie besluit geneem teen 'n horison wat daaraan betekenis gee. Die ideaal van outentisiteit kry juis sinvolheid teen die agtergrond van Quixote, Jeanne en Rosette, persone wat 'n hoë premie plaas op 'inteendeel sê', persone wat ingaan juis teen dit wat die ander aanvaar en hulle eie lewens herskryf.

* Don Quixote wat die belang van fiksie, van dit waarin jy glo bo die werklikheid stel (178), wat die illusie verkies bo die werklikheid;

* Jeanne wat vir Barbier ' $n$ aanmoediging is om nie die lewe te aanvaar soos dit is nie nie; om inteendeel te sê. Sy het die eerste keer aan Barbier verskyn toe hy nie bereid was om sy lot te aanvaar nie, toe hy die eerste keer 'nee' geroep het. Sy inspireer hom tot selfskepping, om sy lot in sy eie hande te neem op dieselfde wyse as wat sy haar lot in eie hande geneem het.

* Rosette, sy ouers, sy vorige vroue en veral die talle geliefdes vorm 'n motiverende agtergrond in sy lewe.

In Inteendeel is die dialogiese aard gewoon so op die voorgrond dat Barbier nie bloot as narsissisties gesien kan word nie. Hy is te bewus van die aangesprokene en van die voorgangers (Rosette, Quixote, Jeanne). Selfs wanneer hy hulle agterlaat, bly die ideaal van outentisiteit hom by - te danke aan die horison van betekenis wat tot stand kom deur die dialogiese aard van sy bestaan.

Die dialogiese aard van Barbier se selfvertelling, teen ' $n$ horison van betekenisvolheid, is 'n geweldig kreatiewe daad; 'n poging om 'te word wat mens is', naamlik: "human beings who are new, unique, incomparable, who are themselves laws, who create themselves" (Nehamas, 1985:335). Dit beteken dat die ideaal van outentisiteit beskou word in die lig van Nietzsche se begrip van "wording' (becoming). As subtitel van Ecce Homo stel Nietzsche (1980:657) "How one becomes what one is". Nehamas (1985:171) dui aan hoe hierdie oproep om jouself te wees deurgaans in die werk van Nietzsche voorkom. In Nietzsche se werk val die klem op become en nie op is as bereikbare ideaal nie. Wording is 'n proses wat nie lei tot 'n vaste subjek (dit wat mens is) nie. Die klem val op die daad van wording, nie op die resultaat nie. Ook Barbier is geen vaste subjek wat deur die vertel van die storie uiteindelik bloot ont-dek word nie. Die skryf(vertel-)proses self is belangrik. Hierdie proses kan nooit afgehandel wees nie; dit bly 'n proses. Rorty (1989:98) interpreteer Nietzsche soos volg: "In the sense Nietzsche gave the phrase 'who one actually is' does not mean 'who one actually was all the time' but 'whom one turned oneself into in the course of creating the taste by which one ended up judging oneself". Onmiddellik verdui- 
delik hy egter dat wat hy met "ended up" bedoel nie 'n voorafbepaalde rusplek is nie maar dat die proses van herbeskrywing sal voortduur tot 'n mens se dood; "... the process of becoming aware of one's causes by redescribing them is bound to be still going on at one's death" (Rorty, 1989:99). Barbier vorder steeds nader aan die bereiking van wat hy is: "wat ek is is ek vinnig aan die word" - dit is egter steeds 'n wordingsproses. Elke storie is voorlopig - ook elke storie wat hy vertel, word weer voortdurend opgehef en eindig met sy dood - maar ook die beskrywing van sy dood word gevolg deur sy eie handtekening (kyk afdeling 4.2.1 Sous rature hieronder).

\subsection{Metafiksie}

Die idee van die bereiking van 'n vaste self, die ontdekking van 'n finale self, word in die wiele gery deur die klem wat op die talige aspek van die roman geplaas word. Coetzee (1993:7) wys daarop dat die vertelling van Barbier ooglopend nie al is waaroor die roman gaan nie, maar dat die klem veral op die talige aspek van die teks val.

Waugh (1984) beskou metafiksie as die sistematiese en opsetlike vestiging van die aandag op die kunsmatigheid, die fiksionele aard van 'n teks. Deur metafiksie word die leser se aandag daarop gevestig dat die wêreld in sy geheel of gedeeltelik ' $n$ taalgestruktureerde werklikheid is. Lauzen (1986), in navolging van Waugh se definisie, wys op die graad en intensie van metatekstuele kommentaar. 'n Teks is eers metafiksioneel as daar oorvloedige en sistematiese gebruik van metafiksionele tegnieke gemaak word:

The message in all fully metafictional novels is at least partly 'art is artiface'; we are made conscious in some way that any message comes to us via processing of language by both author and reader. In a metafictional work, the device that points to itself (and us) has some significant weight in the novel as a whole. (Lauzen, 1986:95.)

Die effek van sistematiese metafiksionele ingrepe is dat die grens tussen teks en werklikheid vervaag. (McHale (1987) wys byvoorbeeld daarop dat metafiksionele ingrepe in die roman ontologiese twyfel tot gevolg het.) Die estetiese word uitgebrei na die lewe. Dit is immers wat reeds gebeur met Barbier se selfskepping. Die estetiese en 'wêreld' word geïntegreer. Waugh (1992:18) voer aan dat hierdie integrering beskou kan word as "an extension and democratisation of the aesthetic, an attempt to integrate it into life as a mode of imaginative realisation and empathy which can widen our human sympathies..."

Storievertel word in Inteendeel voorgehou as 'n magtige (self)skeppende vermoè. Deur metafiksionele kommentaar word egter ook hierdie vermoë geïroniseer. Die 
onbeperktheid van Barbier se selfskeppende mag word gerelativeer. Barbier se gebondenheid aan die diskoers word immers deur metafiksie beklemtoon. Die moontlikheid dat hy nie eens werklik besig is om homself te skep nie word herhaaldelik genoem. Barbier is dus bewus van die voorlopigheid van sy eie woordeskat.

Die belangrikste is die klem wat val op die uitstel van betekenis. Soos wat dit uiteindelik nie vir Barbier moontlik is om sy eie lewe in woorde vas te lê nie - nie die land te begryp in taal nie, geen storie uiteindelik finaal kan vasstaan nie, word ook die poging om dit deur hierdie teks te doen slegs voorlopig. Die verwysings na Derrida $(13,14,304)$, roep ook onmiddellik die talige aspek en die onmoontlikheid van finaliteit van die teks op: "Al wat ek het is my storie. Wat in die vertel vermenigvuldig in ontelbare ander" (14). Hierdie stelling herinner byvoorbeeld aan Derrida (1978:xvi) se term différance, waarmee hy die voortdurende uitstel van betekenis aandui en aan die idee dat geen sentrum bestaan nie, slegs 'n oneindige aantal be-tekendes ${ }^{12}$. Die onvermoë van taal om die werklikheid weer te gee, om enigiets oor die werklikheid mee te deel word hierdeur in gedrang gebring. Die voorlopigheid van enige geskrif, enige taal, word op die voorgrond geplaas.

Coetzee (1993:7) wys op die voortdurende onmoontlikheid om die betekende te benoem. Die teken verplaas die werklikheid en verkry mag van sy eie. Die teks word ook 'n mag wat verplaas. "Barbier is therefore replaced by the text, by the writing as supplement; and the text we are reading is Brink's text, the real signified."

Barbier is bewus daarvan dat hy nie self besig is om sy eie lewe te skryf nie, maar dat hy geskryf word, uit 'n ander eeu en ruimte ("Dalk word ek vertel" - 14); dat sy lewe bloot vertelling is - moontlik selfs van iemand wat "oor vyftig of honderd of wie weet tweehonderd-en-vyftig jaar probeer om my te verbeel" (14). Sodoende word die hele diskoers gerelativeer. Barbier kan nie geken word nie. Hierdie aanbieding van sy lewe is bloot fiksie. Van sy werklike motiverings sal ons altyd onbewus bly. Tog het hierdie relativering ook nie 'n opheffing tot gevolg nie. Die bestaan van Barbier word juis bevestig deur die fiksie (153).

12 Derrida (1978.279) stel dit soos volg: "... it was necessary to begin thinking that there was no center, that the center could not be thought of in the form of a prescnt-being, that the center had no natural site, that it was not a fixed locus but a function, a sort of non-locus in which an infinite number of sign-substitutions came into play. This was the moment when languages invaded the universal problematic, the moment when, in the absence of a center or origin, everything became discourse." 
Verskillende moontlikhede is gelyktydig moontlik. Barbier kan besig wees om homself te vertel, maar dit is ook so dat hy eintlik vertel word; hy skryf 'n brief, maar dit is ook nie werklik 'n brief nie. Dit is later onmoontlik om enige ontologiese grond te vind. Dit is belangrik om hierop klem te lê aangesien sodoende bevestig word dat ook die eie vertelling weer ironies gelees kan word. Ook die eie woordeskat is nie finaal nie - uiteindelik moet ook weer daarvoor 'inteendeel' gesê word.

\subsubsection{Sous rature ${ }^{13}$ (die doodtrek van stories)}

Telkens vertel Barbier verskillende weergawes van dieselfde storie. Verskeie weergawes van sy aansluiting by die VOC, die reis na die Kaap en sy ontvangs in Tafelbaai word gegee. Die verskillende weergawes is dikwels fantasieryk (hulle praat Latyn met inboorlinge, die goewerneur het twee mak leeus as troeteldiere, ens.). Uiteindelik is dit onmoontlik om enige van hierdie stories as 'die waarheid' te beskou. 'Dié Waarheid' bestaan nie, hoogstens verskillende weergawes daarvan. "Wat my nogal fassineer is dit: hoe elke storie 'n ander verplaas, maar sonder om hulle ooit heeltemal te verplaas of uit te wis" (114).

Elke nuwe weergawe van 'n vorige verhaal verplaas die vorige, maar kan dit nooit uitwis nie. Deur dieselfde verhaal op verskillende maniere te vertel, word die vorige telkens opgehef - dikwels selfs deur 'n erkenning dat die vorige weergawes nie waar was nie. Tog sou die hele verhaal, die 'brief' van Barbier, nie meer dieselfde wees as sogenaamd verkeerde weergawes weggelaat sou word nie. Hulle teenwoordigheid in die teks het gedurig 'n relativerende invloed op al die ander weergawes. Die moontlikheid dat die nuutste weergawe ook weer verplaas kan word, word op hierdie wyse beklemtoon.

Genommerde afdelings volg dikwels op mekaar met weersprekende weergawes van dieselfde storie, of kommentaar op die vorige afdeling. Dit word ' $n$ belangrike tegniek om afdelings met mekaar te laat kommunikeer, en die invloed van die een afdeling/storie op die ander word hierdeur bevestig. Geen vorige storie word opgehef nie. Telkens word die vorige bloot 'verplaas' maar bly sous rature staan. Al die afdelings staan ook neweskikkend - almal bloot genommer van 1 tot 300 . Die een hef nie die vorige op nie.

13 In Of (irammatology (1976) gebruik Derrida die term sous rature (under erasure) om te wys op sekere terme wat nie werklik aanvaarbaar of legitiem is nie maar wel in die teks mgesluit word - maar dan deurgehaal op so 'n wyse dat dit steeds leesbaar bly. Hier word dic term gebruik in oorecnstemming met dic betekenis wat McHale (1987:100) daaraan toeken. Die leser word betrek by dic skepping van 'n 'wêreld' wat net weer weggeneem word. 
Barbier erken dikwels dat sy stories fantasieë is; dat hy dit vertel soos hy graag sou wou hê dit moes verloop. Hy vertel byvoorbeeld hoe hy Alleman afransel en aan sy skrotum aan die klok ophang. Ten spyte daarvan dat hy later erken dat dit nie gebeur het nie, en die storie dus sodoende opgehef word, word weer telkens op ander geleenthede sydelings verwys na die uitgedroogde skrotum wat steeds aan die klok swaai (123).

Hierdie onsekerheid oor wat dan eintlik die waarheid kan wees, brei uit om ook die dokumente wat deur die leser as 'waarheid' aanvaar word, in te sluit. Die hofverslae uit die Staatsargief wat die outeur ook in die erkenning vermeld, kan uiteindelik met dieselfde agterdog bejeën word as alle ander vertellings. Barbier beskuldig De Granpreez daarvan dat hy die hofstukke vervals het, dat dit nie 'n korrekte weergawe van die verloop van die hofverrigtinge is nie. Hy onthou dan ook hoe Mentzel sy joernaal oorgeskryf het (en die waarheid sodoende vervals het) en selfs hoedat hy self ook reeds die joernaal volgens Alleman se wense geplooi het. Gevolglik kom hy tot die gevolgtrekking dat enige geskrif leuens is: "Wie pen op papier sit, lyk dit my, lieg" (170). Ook die hofverslae is dus bloot nog 'n weergawe van die gebeure, moontlik leuens. Nietemin is sulke weergawes al wat ons het om in te glo. Op 'n beskuldiging van Barbier dat sy tevore 'n ander storie aan hom vertel het, reageer Rosette met die vraag: "Wat maak dit saak wat ek vertel het" (65)? En later verduidelik sy dat stories die enigste ding is wat sy het om in te glo. Feite, waarheid is nie vindbaar nie: "Wat anders kan ek glo?" wil Rosette weet (65).

Die herhaling van die idee dat hierdie brief van Barbier nie werklik geskryf word nie en dat die geadresseerde ook nie werklik kan lees nie, het 'n relativerende, ironiserende effek. Dit wat gelees word, is tog nie werklik geskryf nie, en kan nie gelees word nie. Tog het die leser nou al alles tot hier gelees, en kan dit nie weer uitgewis word nie, selfs so 'n relativering van die hele teks kan nie die teks ophef nie; relativering kan hoogstens finale betekenis uitstel (124-125). Weer eens is die proses van belang en nie 'n produk van finale betekenis en waarheid nie.

Deur die ontologiese twyfel wat ontstaan weens die voortdurende verplasing van verskillende 'stories' word die leser se aandag uiteindelik gevestig op die onmoontlikheid van enige legitimering. Geen finale 'Waarheid' kan gevind word nie. Soveel nuwe stories as wat vertel kan word, soveel legitimerende metanarratiewe kan geskep word, wat elk weer 'n eie diskoers tot gevolg kan hê.

\section{Gevolgtrekking}

Die proses van selfskepping: om deur middel van die vertel van die eie verhaal, om die self oor te vertel, is ' $n$ integrasie van die estetiese en die lewe. Skeiding 
tussen narratief en lewe is gevolglik nie meer moontlik nie. Deur hierdie skeiding op te hef word gehoop op die skepping van 'n 'beter' eie lewe, 'n meer menslike lewe - sonder die voortdurende skade aan ander; in vrede met Afrika en sy inwoners - daarom dat Barbier absolusie soek tydens sy derde reis. Deur hierdie proses word gehoop op die skep van 'n meer simpatieke en menslike wêreld.

Vir Barbier is sy vertelling, die brief, 'n poging om die onmoontlike reg te kry, om vir Rosette op te roep en ook by ander mense uit te kom. Hy besef die nutteloosheid van taal, maar bly nietemin hoop:

En deur dit vandag hier aan jou te skryf - Rosette, Rosette: dit is nog steeds die enigste naam waarmee ek jou kan oproep - moet ek probeer om deur jou ook by ander uit te kom. Daar is geen waarborg nie: ek is dood, jy kan nie lees nie; ek het dit al gesê. Maar dis die moeite werd om te probeer. Miskien was dit waarom Jeanne bereid was om soveel jare lank by my te bly. Ek kon dit nooit verstaan nie. Verstaan ek dit nou? Ek moet maar hoop. (299)

Hierdie hoop sluit dan ook weer aan by die wording van Nietzsche, by die ironisering van Rorty, die voortdurende uitstel van finale betekenis van Derrida. Al wat bly is hoop. Nie hoop op iets (waarheid/werklikheid/die self) nie, maar hoop as modus van lewe. Hierdie ongedefinieerde hoop is 'n paradoksale hoop. Barbier weet by voorbaat dat hy nie kan skryf nie en Rosette nie kan lees nie, maar hy gaan aan om te probeer. Die outeur besef dat taal nie die werklikheid kan meedeel nie; nogtans hou die outeur nie op met skryf nie. Die poging, die proses, is dit waarop die klem val en nie op die eindproduk - 'n mededeling omtrent die werklikheid - nie. En die hoop bestaan dat hierdie poging, paradoksaal, betekenisvol is.

Wanneer selfskepping beskou word in die lig van die verwerping van metaverhale (inteendeel sê) en die herskepping van die self, mag dit lyk soos die vervanging van een metaverhaal deur ' $n$ ander. Juis daarom is dit belangrik om die dialogiese aard van hierdie selfskeppingsproses en die voortdurende ironisering te beklemtoon. Selfskepping is nie 'n afhandelbare proses nie maar wording. Dit beteken dat 'n nuwe metanarratief nie sonder meer onbewustelik aanvaar word nie, maar dat daar die hele tyd 'n poging is om eie vertrekpunte bloot te lê.

\section{Bibliografie}

Bertens, H. \& D'haen, T. 1988. Het Postmodernisme in de literatuur. Amsterdam : Uitgeverij De Arbeiderspers.

Brink, A.P. 1993. Inteendeel. Kaapstad : Human \& Rousseau.

Burger, W.D. 1994. Postmodernisme: Doelgerig of vrolike fuif? 'n Polisieroman en 'n moorddroom. Literator, 15(1):59-72, April. 
Coetzee, A. 1993. Textualising Africa. Southern African Review of Books, 5(6):7-8, Nov./ Dec.

Derrida, J. 1976. Of Grammatology. Baltimore : The Johns Hopkins University Press.

Derrida, J. 1978. Writing and Difference. London : Routledge and Kegan Paul.

Fokkema, D. 1984. Literary History: Modernism and Postmodernism. Amsterdam : John Benjamins.

Foucault, M. 1980. Power/Knowledge. New York : Pantheon.

Hutcheon, L. 1984. Narcissistic Narrative: The Metafictional Paradox. New York : Methuen.

Lauzen, S.E. 1986. Notes on Metafiction: Every Article Has a Title. In: McCaffery, L. Postmodern Fiction: A Bio-Bibliographical Guide. New York : Greenwood Press. p. 93116.

Lyotard, J-F. 1984. The Postmodern Condition. Manchester : Manchester University Press

Mchale, B. 1987. Postmodernist Fiction. London: Methuen.

Nehamas, A. 1985. Nietzsche, Lufe as Literature. Cambridge : Harvard University Press.

Nietzsche, F. 1980. The Porlable Nietzsche. New York: The Viking Press.

Ronty, R. 1989. Contingency, Irony, and Solidarity. Cambridge : Cambridge University Press.

Taylor, C. 1991. The Malaise of Modernity. West Concord : Anansi,

Waugh, P. 1984. Metafiction: The Theory and Practice of Self-Conscious Fiction. London : Methuen.

Waugh, P. 1992. Practising Postmodernism/Reading Modernism. London : Edward Arnold. 